\title{
A qualitative approach to evaluate the reconciliation of GOLDX and OneGram in Islamic Finance*
}

\author{
Marwan Mohamed Abdeldayem ${ }^{1}$, Saeed Hameed Al Dulaimi ${ }^{2}$, \\ Fuaad Hameed Al Dulaimi ${ }^{3}$
}

\begin{abstract}
The purpose of this study is two-folded. The first purpose is to examine the perception of Islamic finance experts and Shariah scholars on the Islamic cryptocurrency (i.e., GOLDX and OneGram). The question is whether it has a role in reconciling cryptocurrency in Islamic finance. The second is to introduce the new Islamic cryptocurrency to serve these rich Islamic populaces. The study used a qualitative research approach by conducting interviews to explore the Islamic scholars' views on the framework of the new Islamic cryptocurrency. The scholars have been deemed to meet particular requirements of having comprehensive knowledge and have extensive experience in both the Islamic Shariah and cryptocurrency. Accordingly, the number of such scholars was limited, and eventually, with the access offered only to five scholars from different Islamic countries. We thoroughly analyzed the collected data from the interviews. The findings reveal that Islamic law is absent on the essential models for the conventional cryptocurrency utilization(such as bitcoin) as either a legitimate or illicit apparatus exchange device. Consequently, introducing new Islamic cryptocurrencies is to reconcile cryptocurrencies such as GOLDX and OneGram.
\end{abstract}

\footnotetext{
* Received: 09-12-2020; accepted: 18-06-2021

1 Associate Professor of Business and Finance, Cairo University, Egypt and College of Administrative Sciences, Applied Science University (ASU), P.O Box 5055 Manama, Kingdom of Bahrain. Scientific affiliation: corporate finance, behavioral finance and cryptocurrency applied research. Phone: +973 35121048.E-mail: Marwan.abdeldayem@asu.edu.bh.

2 Associate Professor of Business \& HR Management College of Administrative Sciences, Applied Science University (ASU), P.O Box 5055 Manama Kingdom of Bahrain. Scientific affiliation: human resources management and change management. Phone: +973 39998703.E-mail: Saeed.aldulaimi@asu.edu.bh.

3 Assistant Professor of Islamic Finance Bait al-Mashura Finance Consultations, Gulf Cooperation Countries.Email: f.dulaimi@b-mashura.com.
} 
They will play a vital role in attracting more than 1.5 billion Muslims around the globe to enter the world of cryptocurrency.

Key words: cryptocurrency, GOLDX, OneGram, Fintech, Islamic finance

JEL Classification: G15, G32

\section{Introduction}

In societies where Islam prevails, the principles of work, commerce, and daily dealings follow Islamic rules. In Islamic law, it is accepted that monetary movement ought to be founded on genuine, actual resources, not speculation hypothesis; Islamic law also prohibits the payment and collection of interest, also commonly called "Riba" (usury). In this manner, numerous individuals in the Middle East and Gulf Cooperation Council (GCC) do not consider bitcoin, Ethereum, and different cryptocurrencies to be compliant with Shariah law (Abdeldayem and Aldulaimi, $2020 \mathrm{a} \& \mathrm{c}$ ). As a rule, any currency goes about as a mechanism of trade, store of significant worth, and unit of record (see figure 1 below). Two of the principal addresses a public asks before it acknowledges a currency as legal money seem to be "who is issuing this currency" and "is the currency issuer reliable and trusted"?

Digital forms of money have not been formally restricted in Muslim Countries such as Saudi Arabia and the United Arab Emirates yet; however, these legislatures have given admonitions about their residents buying bitcoin (Kusuma, 2020). Along these lines, Muslim business sectors have been slower to exchange advanced monetary standards and get involved in the cryptocurrency markets. Furthermore, there is a great deal of money to be made in Islamic countries: Muslim nations contribute about 9\% of worldwide GDP. As indicated by Price Water House (PWH) coopers (2020), total Islamic finance assets are over $\$ 2.8$ trillion and record for just $1.2 \%$ of all-out worldwide financial resources. To serve these rich Islamic populaces, another kind of Shariah-endorsed crypto is springing up as GOLDX and OneGram.

In societies where Islam prevails, the principles of work, commerce, and daily dealings follow Islamic rules (Ahmed, 2009 and 2011; Velayutham, 2014; Beekun, 1997). Since Muslims are guided by their shariah and fatwa, this study will make a valuable and valuable contribution to the literature at both the theoretical and practical levels. At the theory level, this study-to the best of our knowledge- is the first of its kind to evaluate the new Islamic cryptocurrency, and hence it adds to the international body of literature in this field. The results of this research will provide empirically based information on the perception of Islamic finance experts and Shariah scholars on whether Islamic cryptocurrency (i.e., GOLDX and OneGram) would play a role in reconciling (accommodating and conforming) cryptocurrency in Islamic finance. This study also contributes to the larger area of Islamic finance theories by highlighting the effect of Islamic cryptocurrency on reconciling cryptocurrency in Islamic finance. At a practical level, this research will also contribute to policymakers' evaluation of the 
new Islamic cryptocurrency to serve these rich Islamic populaces, as this would attract more than 1.5 billion Muslims around the globe to enter the world of cryptocurrency, as well as contributing to the improvement of cryptocurrencies management and corporate governance practices. After all, the results revealed from this study will have implications for improvements in practices of Islamic finance and could serve as a guide towards advancing the management and performance of cryptocurrency in the Islamic world. Distinct from most past studies, this study will investigate whether new Islamic cryptocurrencies (for example, GOLDX and OneGram) can accommodate cryptographic money in Islamic accounts. "In this study, the general hypothesis can be stated in the null form as follows: "Islamic Cryptocurrencies (GOLDX and OneGram) have no significant impact on the reconciliation of cryptocurrency with Islamic finance".

The historical development of money began when the Islamic government dominated. It commenced when Prophet Muhammad PBUH governed in the city of Medina in $625 \mathrm{AD}$. The first money was the dinar minted $4.25 \mathrm{~g}$ gold of 22-carat, and dirham made of 3-grams of silver. At that period, the restriction of the prevailing money on the skin of a camel was partly because of the camel populace decrease (Haneef and Barakat, 2002). The dinar replicated from the golden money of the Byzantine Empire, while the silver duplicated from the Persian Empire. These two kinds of money had a steady proportion of 1:10 then varied to $1: 15$ in the extensive stretch (Rashid et al., 2002). Such a vacillation happened due to the storing by certain individuals. Therefore, if an Islamic cryptocurrency (such as GOLDX and/ or OneGram) successfully develops and is used for all Muslim societies, it may serve as alternative currencies against US Dollar as a World reserve currency.

The remaining of this paper is structured as follows: Literature review is in section 2. Section 3 introduces the methodology. Discussion and statistical analysis results are explained in section 4, while conclusions and avenues for future research are in section 5 .

\section{Theoretical Background and Literature Review}

There is a big debate in the literature on the lawfulness of cryptocurrency in Islam (see Siswantoro et al., 2020). Some researchers believe that cryptocurrency is unlawful in Islam. For example, Bakar et al. (2017) discovered three conditions barring cryptocurrency from the class of money. It is characterized by (1) no natural worth, (2) has an unknown holder, and (3) it is flimsy. A comparative study conducted by Meera (2018), who recommended that "Islamic" money ought to be upheld by a resource. Hence, cryptocurrency does not satisfy that necessity. He proposed that to meet the Islamic standards, cryptocurrency ought to be upheld by a genuine resource. Hassan et al. (2020), Nurhisam (2017), and Abdeldayem and Aldulaimi (2020 b) expressed that Bitcoin is not reasonable as money since it is not 
under government guidelines and the dangers and shortcomings are more prominent than the advantages.

On the other hand, as argued by Siswantoro et al. (2020) some scholars argue that cryptocurrency is compliant with Shariah law. Oziev and Yandiev (2018) have perceived the congruity of Bitcoin to Islamic instructing and found that it has no maker, money related to control, or straightforwardness. Some Islamic specialists moreover have different evaluations on this issue. In 2018, the Sharyah Review Bereau in Bahrain (www.shariyah.com) perceives that cryptocurrency and tokens are admissible as money as they meet inclinations for exchange trades other than various essentials, for instance, maal (property), manfa'ah (usufruct), haqq (right), and dayn (commitment). Besides, there are a couple of differentiations among coins and tokens. Tokens are moreover varied be that as it may, the limit as a method of exchange is relative. Amalin (2018) felt that computerized currency fulfilled for money exchange it is a direct and clear rule for trading. It doesn't contain usury (riba), which is confined in Islamic educating. Near reasons proposed by Zain (2018), who argued that Bitcoin can be used for unlawful trades in light of unregulated by national banks.

Finally, compatibility is perhaps the main measurements while examining cryptocurrency speculation conduct among Muslim financial backers (Ayedh et al., 2020). It is important that compatibility in the current study alludes to the compatibility of cryptocurrency venture with the social and cultural estimations of the investors, their strict convictions, their risk profile and inclination and the similarity with their past speculation experience. The basic pertinence is the compatibility of cryptocurrency venture with the Islamic standards of business, which has been vigorously addressed by academicians, specialists and Islamic researchers the same. The issue of high gharar related with cryptocurrency speculation has been the essential worry as cryptocurrency has no actual structure and exists just in an online network, it has no characteristic worth and cannot be recovered against genuine monetary forms. Besides, the cryptocurrency holders and administrators are mysterious, its worth is flimsy on account of high instability, and it does not qualify as a decent store of significant worth (Abu Bakar et al., 2017). These perspectives were upheld by Meera (2018), who likewise noticed that money without natural worth has a component of unfairness, and henceforth, it is not viable with the target of Islamic guidelines (maqasid al-shariah). Essentially, Hayes (2017) set up that cryptocurrency misses the mark regarding satisfying the standards of the safeguarding of abundance in Shariah, and neglects to have the currency ascribes (Thamaniyyah), which is a characterizing trait of money. Additionally, Nurhisam (2017) broke down cryptocurrency from the Islamic viewpoint and found that it causes a few damages (Madharrat) including the chance of falsifying, loss of certainty and excessive inflation. Likewise, they reasoned that money ought to be given and overseen by state specialists (Ulil Amri). These issues are relied upon to altogether affect the use and reception of Islamic cryptocurrency by Muslims. 
However, the authors of this research effort believe that cryptocurrency needs further investigation to examine the appropriateness of Islamic teaching. This supposition was as that of Asif (2018), who expressed that the framework of cryptocurrency is neither against Islamic teaching nor the derivatives. Furthermore, Bangash (2017) raised comparative issues. He expressed that serval Islamic scholars, (for example, Imam Ibn Taymiyyah, Imam Abu Hanifa, and Imam Abu Yusuf) did not explicitly expand on the necessity of money. They allowed regarding money as an item with certain limitations.

\subsection{Component of Cryptocurrency}

A cryptocurrency is a "virtual coin" and does not exist physically. The main evidence of responsibility is a recorded exchange on the blockchain. The blockchain is an openly available report (or electronic record) as illustrated below in figures 1 and 2. Individuals who own cryptographic money, for instance, need to purchase merchandise from vendors ready to acknowledge cryptocurrency as installments. Instead of having a bank encourage the exchange of the money, that move happens through the public record framework (Abdeldayem et al., 2020; Abu Bakar et al., 2017; Bakar and Rosbi, 2017)

Figure 1: Cryptocurrency Transaction Procedure

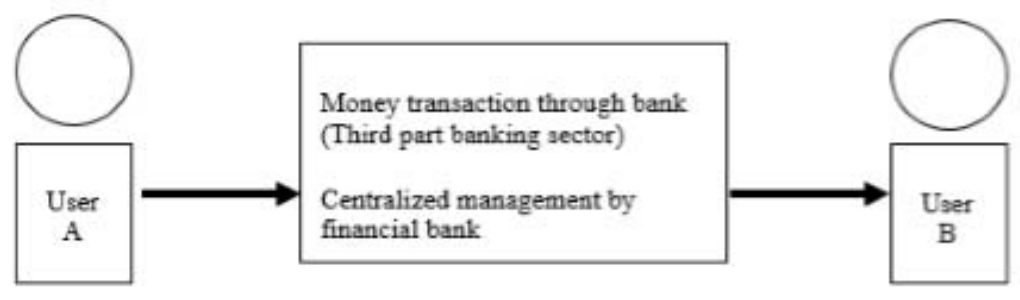

Figure 1: Money transaction procedure

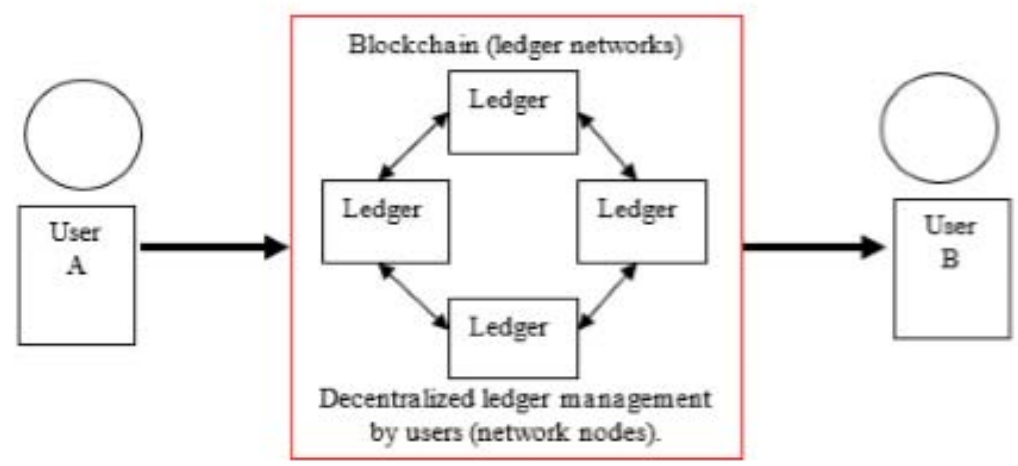

Source: Abu Bakar et al. (2017) 
The inception of another cryptocurrency ordinarily emerges when an organization intends to dispatch new items and discover assets to create them. Cryptographic forms of money work as a mode of trade, a unit of record, and additionally a store of significant worth however do not have lawful delicate status in any ward. It is not given or ensured by any administration and capacities simply by arrangement inside the restricted network of clients. Cryptographic forms of money are unique concerning fiat currency or "genuine money", which is the actual money that makes up any nations legitimate delicate, and they are likewise not quite the same as e-money, which is a computerized portrayal of fiat currency (Han et al., 2018; Rahim et al., 2019).

Figure 2: Blockchain Network (open ledger network)

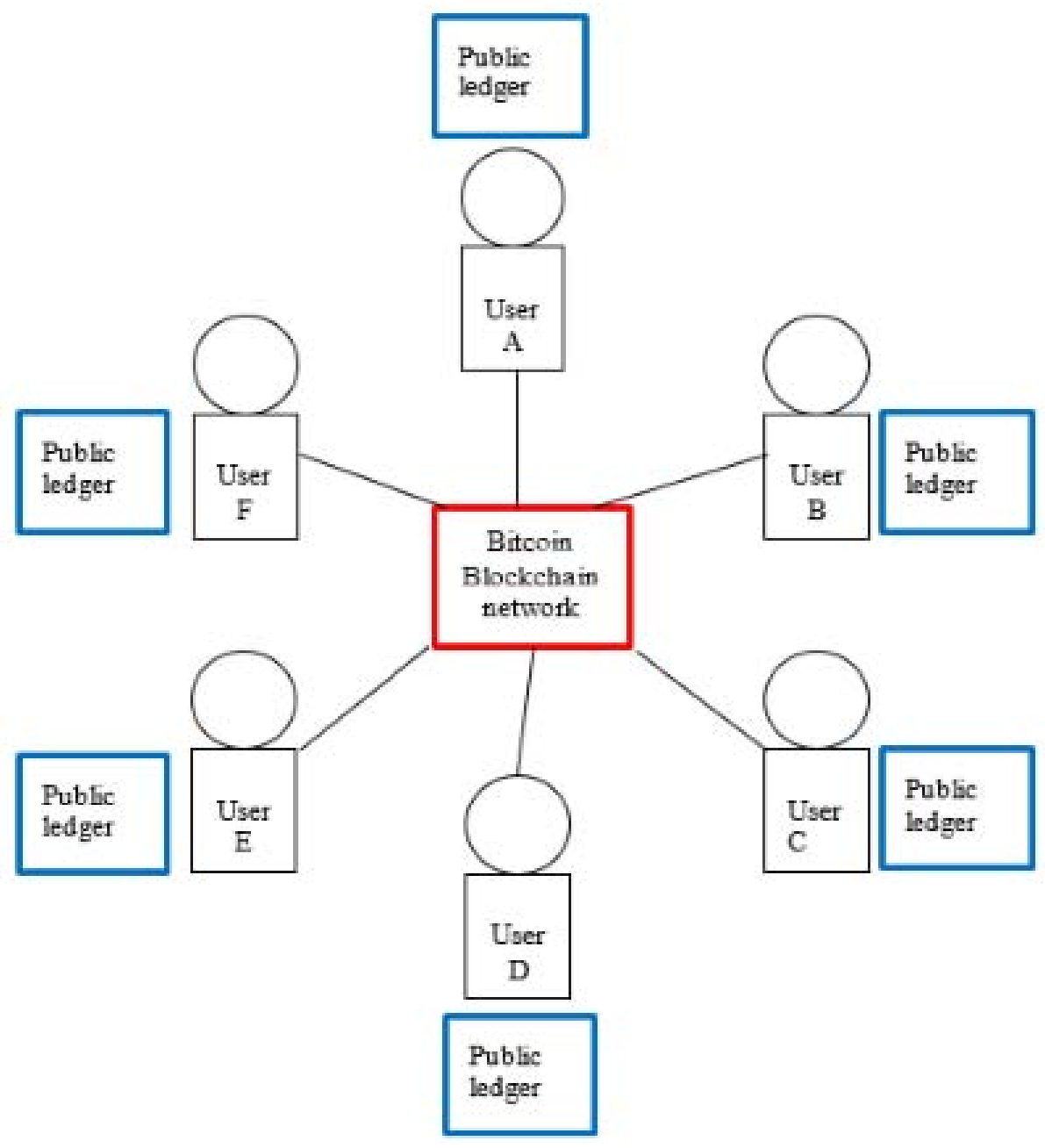

Source: Abu Bakar et al. (2017) 
Throughout the most recent couple of years, the market capitalization of digital forms of money, prominently known as cryptocurrencies, has arrived at a close $\$ 400$ billion with more than 1500 monetary standards been made. Among them, bitcoin has been the most famous and favored one with a current market capitalization of over $\$ 150$ billion. Figure 3 shows the most common cryptocurrencies along with their market capitalization. It can be seen from figure 3 that Bitcoin has the highest market capitalization, while XMR and ZRX were having the lowest market capitalization in 2020. In the light of such developing fame, it merits investigating whether cryptocurrencies, for example, bitcoin or a comparative framework can make an elective mechanism of trade in Islamic money when contrasted with customary Ribaupheld national bank fiat money (see Ayedh et al., 2020; Bakar and Rosbi, 2018).

Figure 3: Market Capitalization of Most common Cryptocurrencies in 2020

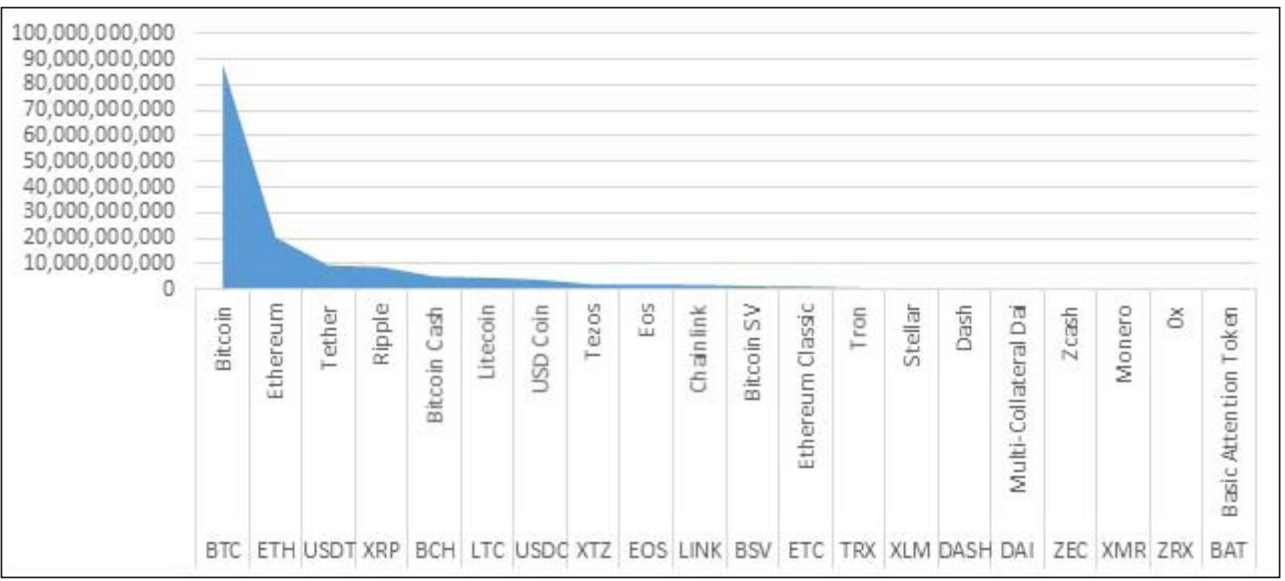

Source: Prepared by authors based on data from Coin Market Cap (2020)

\subsection{GOLDX}

In 2017, a Singapore-based financial technology (fintech) organization called "HelloGold" (HGF) has presented an altcoin named GOLDX that may revolutionize the entire cryptocurrency market. It may very well be the steadiest yet. In reality, when cryptographic money plunges to $30 \%$ of its incentive in seven days, this is particularly significant. GOLDX is a token based on Smart Contract technology built on the Ethereum ERC20 Blockchain. Each GOLDX token is represented by one (1) gram of investment-grade physical allocated gold securely vaulted with and insured by a bullion custodian in Singapore i.e. Bullion Star International.

Hence, users and financial specialists can buy GOLDX with Bitcoin or Ethereum, two of the greatest digital forms of money out there. Nonetheless, where it varies is in its sponsorship by actual gold. One GOLDX is consistently attached to $1 \mathrm{~g}$ of gold, 
making it an "anchor of strength" to cryptocurrency speculators. This gold is put away in a protected vault in Singapore, cared for by overseer "BullionStar" Singapore. Furthermore, table 1 below summarizes the main features of GOLDX such as the acquisition of gold; Technology; management fees, and how to acquire GOLDX.

\section{Table 1: GOLDX Summary and Mechanism}

\begin{tabular}{|c|c|}
\hline Items & Description \\
\hline Key Features & $\begin{array}{l}\text { - GOLDX is issued on the block chain as and when gold is deposited into HGF's } \\
\text { gold account and upon approval by } 3 \text { authorized signatories including from } 1 \\
\text { Director of HGF. The issuance process will be done on the same day; } \\
\text { - GOLDX issued belongs to HGF and can be traced at the HGF public address. The } \\
\text { information can be verified using the Ethereum block search; } \\
\text { - GOLDX is backed by real physical allocated gold, where 1GOLDX =1g of gold; } \\
\text { - No limit of issuance; } \\
\text { - Each GOLDX is divisible up to } 18 \text { decimal points; } \\
\text { - Any transfer of GOLDX between the parties (crypto wallets) will require a small } \\
\text { amount of transaction fee in Ether since it is built on the Ethereum blockchain. }\end{array}$ \\
\hline $\begin{array}{l}\text { Acquisition } \\
\text { of gold }\end{array}$ & $\begin{array}{l}\text { - HGF will purchase the gold from its supplier Bullion Star International; } \\
\text { - Pursuant to the purchase, HGF will receive the allocated gold into its account on } \\
\text { the same day (T0); } \\
\text { - HGF will earn management fee from its Customers in the form of gold; } \\
\text { - HGF has committed to allocate a fixed amount of grant endowment to HGF on a } \\
\text { monthly basis amounting to } 10 \% \text { of its revenue earned from the management fee; and } \\
\text { - HGF shall receive the amount of allocated gold into its account as endowment, } \\
\text { which is confirmed by way of Customer's gold holding position in the HGF's } \\
\text { website (updated on daily basis). }\end{array}$ \\
\hline Technology & Ethereum ERC20 - Blockchain based technology \\
\hline $\begin{array}{l}\text { Management } \\
\text { Fee }\end{array}$ & $\begin{array}{l}\text { - GOLDX is backed by real allocated physical gold stored in the HGF's gold vault. } \\
\text { Therefore, it is subject to management fee charged by HGF which is } 2 \% \text { p.a. } \\
\text { - The management fee formula is embedded into the GOLDX Smart Contract and is } \\
\text { calculated daily. } \\
\text { - Hence, the amount of GOLDX will decrease on a daily basis at the rate of } 2 \% \\
\text { p.a., and therefore, the amount of GOLDX will also be less than the HGF's gold } \\
\text { amount (because the information on the management fee in the website will be } \\
\text { updated at month end). }\end{array}$ \\
\hline $\begin{array}{l}\text { How to } \\
\text { Acquire } \\
\text { GOLDX }\end{array}$ & $\begin{array}{l}\text { Currently, there are two (2) ways of acquiring GOLDX which are as follows: } \\
\text { i. "Hibah", or gift } \\
\text { HGF may distribute GOLDX to the HGT holder on a discretionary basis. } \\
\text { ii. "Over the counter Purchase" } \\
\text { GOLDX can be purchased via over the counter (OTC) process from HGF using } \\
\text { Ether or Bitcoin. Minimum purchase is } 1 \text { GOLDX. }\end{array}$ \\
\hline Tradability & $\begin{array}{l}\text { - GOLDX are currently tradable based on peer-to-peer transaction between parties } \\
\text { on the Ethereum blockchain, therefore, Ethereum wallet is required; } \\
\text { - Holder of GOLDX can choose to sell the token in open market or opt to sell back } \\
\text { to the HGF at a fixed percentage below the market price of gold. Minimum selling } \\
\text { back to HGF is set at } 1 \text { GOLDX. }\end{array}$ \\
\hline
\end{tabular}

Source: Prepared by authors 
It is believed that GOLDX's meets the adhering conditions that fulfill Shariah law limitations:

- The cycle of purchasing and selling is adequately straightforward

- It is sponsored by actual gold that is completely apportioned

- The cycle of purchasing and selling actual gold is finished in the time permitted by the norm.

The Shariah Compliance measure was directed by a Malaysian firm called Amanie Advisors, a group of Islamic scholars who keep up and guarantee the respectability of the cycle. In contrast to other virtual monetary standards, GOLDX includes the issuance of a token sponsored by actual gold put away in a vault in Singapore, and exchanges must be finished inside a characterized time. The recorded terms supposedly ensure straightforwardness, conviction and instantaneousness of exchanges, which are the essential standards for Islamic financial agreements. The progression may help the number of fintech partnerships ready to venture into Islamic account markets, opening up such areas as the Middle East and Southeast Asia.

Furthermore, in 2017 HelloGold dispatched a blockchain-based versatile application in Malaysia. The application, which furnishes clients with an occasion to purchase and sell physical, speculation grade gold, was likewise confirmed by Amanie Advisors. The organization intends to expand its online gold stage in Thailand and different nations. HelloGold is investigating other vague resources for its blockchain innovation. It includes a common electronic record that permits gatherings to follow exchange data through a protected organization.

\subsection{OneGram}

Gold was one of the underlying types of money to be utilized in Islamic countries, which settles a decent decision for a UAE gold-based digital money (i.e., OneGram) expecting to agree with Sharia law. Since that point, millions of dollars of OneGram coins have effectively been given. It represents about $60 \%$ of the complete proposed to be shared out. In 2018 the UAE introduced a new cryptocurrency called OneGram, sponsored by one of the global most-steady resources: gold. OneGram's pitch means that every unit of significant worth is sponsored by an actual gram of gold kept in a safe. Accordingly, it restricts volatility and speculation and has been esteemed satisfactory under Islamic standards by Dubai-based al-Maali consulting. Gold remains generally steady, floating somewhere within the range of $\$ 1,200$ and $\$ 1,350$ for as far back as a year, while Bitcoin cost changes broadly every day. While in the wake of moving to an unequaled height of almost $\$ 20,000$ in 2017, the cost dropped in 2020 , sitting at the season of composing at $\$ 7,000$. 
The tokens presently matched for exchanging against Bitcoin, the organization intends to add pairings to a few hard monetary standards. The coins are recorded on the company's trade, known as "Hulk", and future postings would focus on provincial trade in Asia and the Middle East. OneGram has sold around $\$ 400$ million worth of its gold-sponsored tokens over the previous year, part of a developing number of Fintech firms entering the field of Islamic finance. In customary business sectors, the cost of gold is regularly utilized as the estimating bar for the status of the worldwide economy. It is because it is a shield against financial turmoil or the expansion of fiat money; if the securities exchange crashes, speculators would have still got the resources in a safe. The idea of gold being a sure thing, as opposed to a bet, consequently, additionally adjusts itself more intimately with Shariah's anti-risk rules.

\section{Methodology}

In general, there are four types of personal interviews: structured, semi-structured, unstructured, and group interviews (see May 1993). The structured interview has the same disadvantages as the face-to-face questionnaire since they both include predetermined questions. Thus, the interviewer has no freedom to probe or get additional information. The unstructured interview is also unsuitable for this analysis since it is time-consuming and impractical from the interviewee's point of view. The group interview method is not desirable either, as the main purpose is to reach some form of triangulation. Given the purpose as well as time and resource constraints, we have adopted the semi-structured interview. This type of interview allows the researcher to have control over time, content, and the sequence of interviews, allowing the interviewer to probe and the interviewee being more or less free in responding to the questions.

Guided by the unique purpose of the study, the intention was to undertake a series of semi-structured interviews with several Islamic finance experts and Shariah scholars from different Islamic counties. The aim was to analyze the overall impact of the Islamic cryptocurrency (i.e., GOLDX and OneGram) on accommodating cryptocurrency in Islamic finance. It was deemed necessary that scholars should meet certain requirements of having comprehensive knowledge and have exhaustive experience in both the Islamic Shariah and cryptocurrency. In short, the criteria utilized for selecting the interviewees are as follows:

1. They should have comprehensive knowledge and experience in both Islamic Shariah and cryptocurrency i.e. they should have at least 5 years of working experience in the field of Islamic finance and/or cryptocurrency.

2. They are either from top academic institutions or distinguished Fatwa bodies. 
Accordingly, the number of such scholars was limited. Thus, the number of interviewees selected in this study and who met the above criteria is 10 Islamic finance experts and Shariah scholars from 8 different Islamic countries. However, due to the problem of inaccessibility and the time scale. The results showed that eventually, only five scholars had access. The small number of interviewees selected is not considered to be a major constraint or limitation since it is felt to be representative. It is an opportunity to gather invaluable information from highranking scholars and experts with many years of work experience and were also involved in both the Islamic Shariah and cryptocurrency (Sutton and Austin, 2015; Al-hussaini et al., 2019).

The data collection procedures incorporate defining the limits for the study, gathering information through semi-structured interviews, archives, and visual materials, just as setting up the convention for recording data. In this research effort, purposive sampling has been selected. The explanation behind picking this sampling strategy is to select participants that will best assist the researchers of this study to comprehend the issue and the interview questions. The research instrument for this study used open-ended questions. These questions have been approved and validated by Islamic finance and Shariah specialists before conducting the interviews. Consequently, after approval and ensuing redresses of the instrument, we developed the following interview questions:

1. What is your opinion on using cryptocurrency by Muslims?

2. Do you think cryptocurrency is (Halal) lawful or (Haram) prohibited in Islam?

3. Regarding GOLDX and OneGram as the first Islamic crypto, how do you evaluate their role to reconcile cryptocurrency in Islamic finance?

4. What are your recommendations to ensure the spread of cryptocurrencies among users in the Islamic world?

The interviews were performed from $10^{\text {th }}$ September 2020 to $19^{\text {th }}$ November 2020. The interview has been conducted with five participants; this small number of interviews is defended by Creswell and Clark (2017) and Al-hussaini et al. (2019) to be fitting for qualitative studies. This is one way to deal with the sample size issue, which harps on the possibility of immersion for building up a grounded hypothesis. As indicated by Gentles et al. (2015) data collection should stop even with two interviewees when the themes are explored. Consequently, the participants for this examination are sufficient to create a solidly grounded hypothesis, the profile of the interview participants, dependent on the proficient ground are introduced in Table 2: 
Table 2: Profile of Interviews' Participants

\begin{tabular}{|c|l|}
\hline Participant ID & \multicolumn{1}{c|}{ Professional Background } \\
\hline P1 & Managing Director and CEO of Bait al-Mashura Finance Consultations - GCC \\
\hline P2 & Professor of Economy and Islamic Banking-Zarqa University - Yemen \\
\hline P3 & Associate Prof. of Islamic Law International Islamic University - Malaysia \\
\hline P4 & Shariah Consultant- Amanie Advisors - Malaysia \\
\hline P5 & $\begin{array}{l}\text { Associate Professor of Islamic law and Economy - King Khaled University - } \\
\text { Kingdom of Saudi Arabia }\end{array}$ \\
\hline
\end{tabular}

Source: Prepared by authors

\section{Empirical data and analysis}

As mentioned earlier, guided by the unique purpose of the study, the intention was made to undertake a series of semi-structured interviews with several Islamic finance experts and Shariah scholars from different Islamic counties to further ascertain the overall impact of the Islamic cryptocurrency (i.e. GOLDX and OneGram) on accommodating cryptocurrency in Islamic finance. The interview that has been conducted with five participants has been analyzed in four themes as shown below.

\subsection{The Use of Cryptocurrency by Muslims}

The use of cryptocurrency by Muslims has been revealed by P1, as "Cryptocurrency for Muslims is the same as other innovative products. He/she can use it as long as it is in line with the Shari'ah principles". In line with this P3 adds, "It is a good innovation that has the potential to benefit the Ummah". P4 also agrees with this point of view and indicates, "There are many types of cryptocurrency and from fiqh perspective; we consider whether something is (Maal) - which meaning is anything tradable or is something storable and usable as utility and it is lawful. Therefore, any asset is Maal and utility then it is (Hala) lawful. Hence, this is the first thing we have to check whether it is a currency or intangible asset. Based on this, a cryptocurrency certainly has some of the utility because it is the usable and stable value used by several sectors and used as approval of ownership and so forth". However, P2 and P5 have a different opinion. P2 indicates, "I think cryptocurrency is still confined to some Arab and Muslim investors to get quick profits, especially in previous years". P5 also reveals, "The use of cryptocurrencies among Muslims is essentially dependent on the issuance of legal fatwas permitting dealing with them by respected Shariah bodies, in addition to the difference in the fatwa on such contemporary issues that will make dealing with them among Muslims limited as they will be the subject of dispute among scholars". These different points of views 
mean that cryptocurrency has not been thoroughly investigated by the research community from an Islamic perspective and cryptocurrency may have a better position in the future, but now the fear of dealing with it has become a source of anxiety, and it is plagued by adventure and lack of discipline for most Muslims around the globe. This result is in line with previous studies such as that of Asif (2018), Billah (2019 a and b), Siswantoro et al. (2020), and Bangash (2017).

\subsection{The Lawfulness of Cryptocurrency in Islam}

"My view is it is halal provided that it fulfills the Shariah conditions". This view is supported by previous researchers such as Metawa et al. (2019), Oziev and Yandiev (2018), Zain (2018), Amalin (2018), and the Shariah Review Bureau as discussed by Dikko and Bakar (2018) who confirmed that cryptocurrency and tokens are allowable as money as they meet propensities for trade exchanges.

On the other hand, P4, indicates "I think that cryptocurrency in its current situation does not assist in establishing its legitimacy because the ignorance in it is clear and does not meet the conditions of the commodity or the financial and the difficulty of tracking it ... etc.". P5 adds, "The fatwa regarding the ruling of cryptocurrencies is still pausing in its ruling, as it is still shrouded in mystery, which makes the perception of it among Shariah scholars incomplete, so it is difficult to issue a Shariah ruling on it." Therefore, the limited dealing with cryptocurrency by Muslims without the approval of the sovereign authorities makes the fatwa bodies unable to issue a ruling regarding it. However, if the guardian approves it, then the scope of issuing a fatwa will be inevitable for the fatwa bodies.

\subsection{GOLDX and OneGram to reconcile/accommodate cryptocurrency in Islamic finance}

During the interview, participants were asked about GOLDX and OneGram as Islamic crypto and their ability to reconcile cryptocurrency in Islamic finance. P1, indicates, "Asset-backed cryptocurrencies are in general shariah compliant. However, when it is metal or gold-backed, one should be mindful of shariah rules. For instance, in this regard, AAOIFIs gold standard issued could be helpful to understand how much we can stretch this rule in application". P2 reveals, "Some academic experts across Britain, India, Turkey and Middle East have argued that traditional cryptocurrencies (e.g. Bitcoin, Ethereum) cannot be permissible, and in 2019, the Grand Mufti in Egypt declared that cryptocurrencies shouldn't be traded. The argument around traditional cryptocurrencies is complicated for several reasons, including the fact that there are thousands of digital coins present in the world today, all with their own unique features related to mining, distribution, and trading. This is why some groups-including me - believe that introducing of Islamic cryptocurrencies such as GOLDX and OneGram would open a new avenue 
for the reconciliation of cryptocurrency with Islamic shariah". P3 also confirms, "As it is covered with gold, it is more stable than traditional cryptocurrencies, and can achieve the standards of money considered Shariah. Hence, I strongly believe that Islamic Cryptocurrencies such as GOLDX and OneGram will certainly have significant impact on the reconciliation of cryptocurrency with Islamic finance". While some participants could not provide conclusive answers on the role of GOLDX and OneGram to reconcile cryptocurrency in Islamic fiancé. For example, P4 indicates "I don't know its details". P5 comments "I have not done a Shariah review of this cryptocurrency (GOLDX or OneGram) to determine whether they are Shariah-compliant or not. However, introducing of such Islamic cryptocurrencies would play a vital role in the reconciliation of cryptocurrency with Islamic finance". So this study is seeking to find out if they are fitful the shariah principles investing in gold and whether they ensure that ownership is past and a token is surely assetbacked and know the way are traded and what platform used. Those things must be reviewed to determine whether COLDX and OneGram are Shariah-compliant or not". It can be concluded that GOLDX has been approved as Shariah's compliant gold-backed token. The process of acquiring GOLDX as per the below mechanisms observes the Shariah requirements and principles:

(i) "Hibah", or gift (HGF may distribute GOLDX to the HGT holder on a discretionary basis) or

(ii) "Over the counter Purchase" (GOLDX can be purchased via over the counter (OTC) process from $\mathrm{HGF}$ using Ether or Bitcoin. Minimum purchase is 1 GOLDX).

Therefore, despite some researchers believe that cryptocurrency is unlawful in Islam such as Bakar et al. (2017), Sarea and Hanefah (2013), Alam et al. (2019), Nurhisam (2017), and Kusuma (2020) who argued that cryptocurrency is not reasonable as money since it is not under government guideline and the dangers and shortcomings are more prominent than the advantages. However, the aforementioned sentiments of Islamic scholars strongly support that both COLDX and OneGram can be the remedy to reconcile cryptocurrency in Islamic finance and play a vital role in attracting more than 1.5 billion Muslims around the globe to enter the world of cryptocurrency particularly if governments in Islamic countries start to approve and deal with these Islamic cryptocurrencies.

\subsection{The spread of cryptocurrencies among users in the Islamic world}

Participants also were asked for their recommendations to ensure the spread of cryptocurrencies among users in the Islamic world. P1 reveals, "We need to educate Muslims to take part in the use of this type of assets and benefit from it without violating the principles of Shariah". P3, adds "Definitely it is unstoppable. As such, we need to find ways to ensure that they are shariah compliant. Therefore, 
instead of avoiding it, innovation needs to be used to ensure this". These sentiments indicate that what important is the need for more education on cryptocurrency to increase clarity because the greatest factor would be if a Shariah standard exists like IOF. We confidently need a standard on cryptocurrency. That would be an optimal method by which we will get clarity on this matter and more information will be available for users in the Islamic world. Only then, a great number of Muslims will move towards cryptocurrency trading.

Moreover, P4 expressed his point of view by highlighting that "the spread of cryptocurrencies among users in the Islamic world is a function of adherence to the significant Shariah money standards and controls; and to move away from the known functions of money and not become a place of trade and a commodity". In this regard, as pointed out by Dikko and Bakar (2018) and Nienhaus (2020) Shariah advisory council of the security exchange in Malaysia has already issued a resolution in favor of cryptocurrency to provide guidelines. We need the same thing from IOF and the Shariah standard setting across the world to give more clarity and more knowledge on cryptocurrency about how can be used and Shariah compliance screening criteria for such assets. Finally, in order to ensure the spread of cryptocurrencies, two main entities must approve to deal with them. The first of which is the legal approval by the guardian and the second is the legal approval by the prestigious fatwa bodies in the Islamic world such as Al-Azhar in Egypt; the Permanent Committee for Scholarly Research and Ifta in Saudi Arabia; and the National Fatwa Council in Malaysia.

\section{Results and discussion}

After data collection and analysis of interview data, the researchers reject the null hypothesis and accept the alternative hypothesis that "Islamic Cryptocurrencies (GOLDX and OneGram) have a significant impact on the reconciliation of cryptocurrency with Islamic finance". The collected data from the interviews were thoroughly analyzed. The findings reveal that Islamic law is absent on the essential models for the utilization of the conventional cryptocurrency (such as bitcoin) as either a legitimate or illicit apparatus exchange device. Consequently, the Islamic cryptocurrency model is vital for applying Islamic law to the utilization of cryptocurrency.

Up until now, no single Muslim nation licenses cryptocurrency for lawful exchanges. While it is very hard to recognize the motivation behind utilizing explicit money, because of cryptocurrency, for example, Bitcoin, most users have a theoretical intention to picking up benefits rather than for trade similarly as with money. This is fascinating, as the trait of cryptographic money may not be fluid and stable for change. In the case of supply, not all digital forms of money have 
adequate flexibility to cover all exchanges. Moreover, accessible online dealers, particularly for electronic exchanges, must uphold this. The last issue is steadiness. Cryptocurrency is more unpredictable and volatile than the Standard and Poor itself. This outcome is additionally steady with heartiness tests. Users must know about these attributes. Accordingly, the cryptocurrency might be delegated a mechanism of trade of computerized currency as opposed to money for this classification. Money has adaptable attributes from cryptographic money and its steadiness can be interceded by the government.

Hence, the introduction of new Islamic cryptocurrencies such as GOLDX and OneGram may perhaps be the remedy to reconcile cryptocurrency in Islamic finance and play a vital role in attracting more than 1.5 billion Muslims around the globe to enter the world of cryptocurrency particularly if governments in Islamic countries start to approve and deal with this Islamic cryptocurrency. Ultimately, the Islamic (Ummah) society should have the option to confide in Islamic cryptocurrency as a substantial method for trade unafraid of the superfluous risk of misfortune.

This study will make a valuable and significant contribution to the literature at both the theoretical and practical levels. At the theory level, this study-to the best of authors' knowledge - is the first of its kind to evaluate the new Islamic cryptocurrency, and hence it adds to the international body of literature in this field. The results of this research will provide empirically-based information on the perception of Islamic finance experts and Shariah scholars on whether Islamic cryptocurrency (i.e., GOLDX and OneGram) would play a role in reconciling cryptocurrency in Islamic finance. This study also contributes to the larger area of Islamic finance theories by highlighting the effect of Islamic cryptocurrency on reconciling cryptocurrency in Islamic finance. At a practical level, this research will also contribute to policymakers' evaluation of the new Islamic cryptocurrency to serve these rich Islamic populaces, as this would attract more than 1.5 billion Muslims around the globe to enter the world of cryptocurrency, as well as contributing to the improvement of cryptocurrencies management and corporate governance practices. After all, the results revealed from this study will have implications for improvements in practices of Islamic finance and should be used as a guide towards advancing the management and performance of cryptocurrency in the Islamic world. Distinct from the majority of past studies, this study will investigate whether new Islamic Cryptocurrencies, (for example, GOLDX and OneGram) can accommodate cryptographic money in Islamic accounts.

\section{Conclusions}

The purpose of this study is two folds. First, to examine the perception of Islamic finance experts and Shariah scholars on whether Islamic cryptocurrency (i.e. 
GOLDX and OneGram) would play a role in reconciling cryptocurrency in Islamic finance. Second, to introduce the new Islamic cryptocurrency to serve these rich Islamic populaces, as this may attract more than 1.5 billion Muslims around the globe to enter the world of cryptocurrency. In addition, if an Islamic cryptocurrency (such as GOLDX and/or OneGram) is successfully developed and used for all Muslim societies, it may serve as alternative currencies against US Dollar as a World reserve currency. The study used a qualitative research approach by conducting interviews to explore the Islamic scholars' views on the framework of the new Islamic cryptocurrency. The collected data from the interviews were thoroughly analyzed. The findings reveal that Islamic law is absent on the essential models for the utilization of the conventional cryptocurrency (such as bitcoin) as either a legitimate or illicit apparatus exchange device. Consequently, the Islamic cryptocurrency model is vital for applying Islamic law to the utilization of cryptocurrency.

This study has some limitations. It relied to some extent on official information collected from governmental organizations in Singapore, Malaysia, and UAE. Thus, a caveat should be given regarding the accuracy of this information as it may perhaps include a government bias. A further limitation is that the study considered the views of only five finance experts and Shariah scholars in the interview. The original intention was to interview 10 Islamic scholars from 10 different Islamic countries. However, due to severe access problems as well as the time scale to which the researchers were working, this proved not to be possible especially during the exceptional time of COVID 19. It was only due to the intervention and effort by other colleagues of the five scholars that eventual access was realized.

Despite the above limitations, this study has demonstrated that some future research could be attempted. Prior to distinguishing headings for future studies as shown by this research effort, it is pivotal to deliver the pressing need to set up an advanced international database for the conventional and Islamic cryptocurrencies, which would be useful for both researchers and policymakers. Such data should be maintained via databases to enable researchers to more adequately assess the performance of different cryptocurrencies. Hence, the availability of data would encourage future research and this would also allow governments in Islamic countries to see how things went and facilitate the tasks of decision-makers.

A useful starting point for future research would be to incorporate the perceptions and experiences of other Islamic finance experts and Shariah scholars on whether Islamic cryptocurrency (i.e., GOLDX and OneGram) would play a role in reconciling cryptocurrency in Islamic finance. By conducting the interview utilized in this study to a much larger sample of Islamic scholars and experts will lead to a better understanding based on the experiences of all cryptocurrencies. It should lead to a broader understanding of Islamic cryptocurrency. A study of this nature should perhaps be undertaken in collaboration with some prestigious fatwa bodies in the 
Islamic world such as Al-Azhar in Egypt; the Permanent Committee for Scholarly Research and Ifta in Saudi Arabia; or the National Fatwa Council in Malaysia, as this would have the benefit of making the study official as well as making access to Islamic scholars and experts much easier.

Finally, comparative studies that cover the effect of Islamic cryptocurrency on accommodating cryptographic money in Islamic finance in various Islamic nations are required. Specifically, in the Middle East area and North Africa, as this piece of the world is by all accounts a lot of ignored as far as exploration. These nations have additionally been left out and about cryptocurrency exchanges, and a research study that looks at this would be valuable and would reveal significant insight into the Islamic cryptographic money as this may draw in more than 1.5 billion Muslims around the world to enter the universe of cryptocurrency.

\section{References}

Abdeldayem Marwan, M., Aldulaimi S. H. (2020a) "Cryptocurrency in the GCC Economy", International Journal of Scientific and Technology Research, Vol. 9, No. 2, pp. 1739-1755, http://www.ijstr.org/final-print/feb2020/CryptocurrencyIn-The-Gcc-Economy.pdf.

Abdeldayem Marwan, M., Aldulaimi S. H. (2020b) 'Investors' herd behavior related to the pandemic-risk reflected on the GCC stock markets | Psihologija stada investitora i pandemijski rizik na tržištu dionica zemalja arapskog zaljeva", Zbornik Radova Ekonomskog Fakulteta U Rijeci: Casopis Za Ekonomsku Teoriju i Praksu, Vol. 38, No. 2, pp. 563-584, https://doi. org/10.18045/zbefri.2020.2.563.

Abdeldayem Marwan, M., Aldulaimi S. H., Nekhili R. (2020) "Cryptocurrency as a Fin Tech Instrument and Islamic Finance: The GCC Perspective", Journal of Xi'an University of Architecture and Technology, Vol. 12, No. 2, pp. 27362747, https://www.xajzkjdx.cn/gallery/226-feb2020.pdf.

Abdeldayem Marwan M., Aldulaimi S. H. (2020c) "Cryptocurrency in the Time of Coronavirus", Strad Research, Vol. 7, No. 8, pp. 729-744, https://doi. org/10.37896/sr7.8/073.

Bakar, N. A., Rosbi, S., \& Uzaki, K. (2017) "Cryptocurrency framework diagnostics from Islamic finance perspective: a new insight of Bitcoin system transaction", International Journal of Management Science and Business Administration, Vol. 4, No. 1, pp. 19-28, https://doi.org/10.18775/ijmsba.1849-5664-5419.2014.41.1003.

Ahmed, H. (2009) "Financial crisis, risks and lessons for Islamic finance", ISRA International Journal of Islamic Finance, Vol. 1, No. 1, pp. 7-32, https://www. semanticscholar.org/paper/Financial-crisis\%3A-risks-and-lessons-For-islamicAhmed/551fbf214e92e71a23eea8beb666be03e4fe3656. 
Ahmed, H. (2011) "Maqasid al-Shari'ah and Islamic financial products: a framework for assessment", ISRA International journal of Islamic finance, Vol. 3, No. 1, pp. 149-160, https://dro.dur.ac.uk/9775/.

Alam, N., Gupta, L., Zameni, A. (2019) "Cryptocurrency and Islamic Finance", In Fintech and Islamic Finance, pp. 99-118, Palgrave Macmillan, Cham https:// doi.org/10.1007/978-3-030-24666-2_6.

Al-hussaini, A. I. S., Ibrahim, A. A., Fauzan, M. (2019) "Users Perception of Cryptocurrency System Application from the Islamic Views", International Journal on Islamic Applications in Computer Science And Technology, Vol. 7, No. 1, pp. 13-25, https://www.academia.edu/40871824/Users_Perception_of_ Cryptocurrency_System_Application_from_the_Islamic_Views.

Amalin, G. (2018) "The Legality of Cryptocurrency Trade in Accordance with the Principles of Islamic Banking Law", https://dspace.uii.ac.id/bitstream/ handle/123456789/11715/GAZI\%20 A MALIN\%2014410068. pdf? sequence $=1 \&$ isAllowed $=\mathrm{y}$.

Asif, S. (2018) "The halal and haram aspect of cryptocurrencies in Islam", Journal of Islamic Banking and Finance, Vol. 35, No. 2, pp. 91-101, https://www. academia.edu/37137631/The_Halal_and_Haram_Aspects_of_ Cryptocurrencies_in_Islam.

Ayedh, A. et al. (2020) "Malaysian Muslim investors' behaviour towards the blockchain-based Bitcoin cryptocurrency market", Journal of Islamic Marketing, Vol. 12, No. 4, pp. 690-704, https://doi.org/10.1108/JIMA-04-20190081.

Bakar, N. A., Rosbi, S. (2017) "Autoregressive integrated moving average (ARIMA) model for forecasting cryptocurrency exchange rate in high volatility environment: A new insight of bitcoin transaction", International Journal of Advanced Engineering Research and Science, Vol. 4, No. 11, https://doi. org/10.22161/ijaers.4.11.20.

Bakar, N. A., Rosbi, S. (2018) "Robust outliers detection method for ethereum exchange rate: a statistical approach using high frequency data", The International Journal of Engineering and Science, Vol. 7, No. 4, pp. 1-8, http:// www.theijes.com/Vol7-Issue4.html.

Bakar, N. A., Rosbi, S., Uzaki, K. (2017) "Cryptocurrency framework diagnostics from Islamic finance perspective: a new insight of Bitcoin system transaction", International Journal of Management Science and Business Administration, Vol. 4, No. 1, pp. 19-28, https://doi.org/10.18775/ijms ba.1849-5664-5419.2014.41.1003.

Bangash, A. K. (2017) "An Overview of the Religious Perspective of Honour Killing In Federally Administered Tribal Areas (Fata) of Pakistan", AlIdah, Vol. 34, No. 1, pp. 104-118, http://al-idah.szic.pk/index.php/al-idah/ article/view/85. 
Beekun, R. I. (1997) Islamic business ethics, International Institute of Islamic Thought (IIIT), https://doi.org/10.2307/j.ctvk8w1zv.

Billah, M. M. S. (2019a) Investment in Halal Cryptocurrency, In Modern Islamic Investment Management, pp. 207-223, Palgrave Macmillan, Cham, https://doi. org/10.1007/978-3-030-17628-0_15.

Billah, M. M. S. (2019b) Islamic Cryptocurrency, In Islamic Financial Products, pp. 413-434, Palgrave Macmillan, Cham, https://doi.org/10.1007/978-3-03017624-2_30.

Creswell, J. W., Clark, V. L. P. (2017) Designing and conducting mixed methods research, Sage publications.

Dikko, M., Bakar, M. A. (2018) "A COMPARATIVE REVIEW OF TAKAFUL FRAMEWORKS IN NIGERIA, MALAYSIA AND PAKISTAN”, International Journal, Vol. 3, No. 1, pp. 56-69, http://ijib.uum.edu.my/julai2018/Vol.\%20 3\%20Issue\%201\%2056-69.pdf .

Gentles, S. J., et al. (2015) "Sampling in qualitative research: Insights from an overview of the methods literature", The qualitative report, Vol. 20, No. 11, pp. 1772-1789, https://doi.org/10.46743/2160-3715/2015.2373.

Han, M., et al. (2018) "A novel blockchain-based education records verification solution", In Proceedings of the 19th Annual SIG Conference on Information Technology Education, pp. 178-183, https://doi.org/10.1145/3241815.3241870.

Haneef, M. A., Barakat, E. R. (2002) "A Preliminary Survey of Fiqhi Opinions and Their Implications", Dlm. In Proceedings 2002 International Conference on Stable and Just Global Monetary System-Viability of The Islamic Dinar, International Islamic University Malaysia, Kuala Lumpur: t. pt.

Hassan, M. K., Karimb, M. S., Muneeza A. (2020) "A Conventional and Sharī'ah Analysis of Bitcoin”, Arab Law Quarterly, Vol. 35, No. 1-2, pp. 1-35, https:// doi.org/10.1163/15730255-BJA10067.

Hayes, A. S. (2017) "Cryptocurrency value formation: An empirical study leading to a cost of production model for valuing bitcoin", Telematics and Informatics, Vol. 34, No. 7, pp. 1308-1321, https://doi.org/10.1016/j.tele. 2016.05.005.

Kusuma, T. (2020) "Cryptocurrency for Commodity Futures Trade in Indonesia: Perspective of Islamic Law", In The Name of Allah, The most Beneficent, The most Merciful, http://islamicbanking.asia/wp-content/uploads/2020/04/ Amended-Jan-March-2020-3.pdf\#page=70.

Leung, L. (2015) "Validity, reliability, and generalizability in qualitative research", Journal of family medicine and primary care, Vol. 4, No. 3, pp. 324355, https://doi.org/10.4103/2249-4863.161306.

May, T. (1993) "Social Research, Issues, Methods and Process”, Buckingham: Open University Press. 
Meera, A. K. M. (2018) "Cryptocurrencies from Islamic perspectives: The case of bitcoin”, Buletin Ekonomi Moneter Dan Perbankan, Vol. 20, No. 4, pp. 475492, https://doi.org/10.21098/bemp.v20i4.902.

Metawa, N., et al. (2019) "Impact of behavioral factors on investors' financial decisions: case of the Egyptian stock market", International Journal of Islamic and Middle Eastern Finance and Management. Management, Vol. 12, No. 1, pp. 30-55, https://doi.org/10.1108/IMEFM-12-2017-0333.

Nienhaus, V. (2020) "The Future of Islamic Finance after the Corona Crisis", Bait Al-Mashura Journal, Vol. 13, Special Issue, pp. 173-201. https://doi. org/10.33001/M010820201373.

Nurhisam, L. (2017) "Bitcoin: Islamic law perspective”, QIJIS Qudus International Journal of Islamic Studies, Vol. 5, No. 2, https://oi.org/10.21043/qijis. v5i2.2413.

Oziev, G., Yandiev, M. (2018) "Cryptocurrency from Shari'ah perspective", Al Sharajah, Vol. 23, No. 2, pp. 315-337, https://boiv.org.au/wp-content/ uploads/2020/08/SSRN-id3101981.pdf.

Rahim, N. F., Bakri, M. H., Yahaya, S. N. (2019) "Fintech and Shariah Principles in Smart Contracts", In FinTech as a Disruptive Technology for Financial Institutions, pp. 207-220, IGI Global, https://doi.org/10.4018/978-1-52257805-5.ch009.

Rashid, A. M., et al. (2002) "Getting to know you: learning new user preferences in recommender systems", In Proceedings of the 7th international conference on Intelligent user interfaces, pp. 127-134, https://doi.org/10.1145/502716.502737.

Sarea, A. M., Hanefah, M. M. (2013) "The need of accounting standards for Islamic financial institutions: evidence from AAOIFI", Journal of Islamic Accounting and Business Research, https://doi.org/10.12816/0031381.

Seale, C. (1999) "The Quality of Qualitative Research" London: SAGE. https:// doi.org/10.4135/9780857020093.

Siswantoro, D., Handika, R., Mita, A. F. (2020) "The requirements of cryptocurrency for money, an Islamic view", Heliyon, Vol. 6, No. 1, https://doi. org/10.1016/j.heliyon.2020.e03235.

Sutton, J., Austin, Z. (2015) "Qualitative research: Data collection, analysis, and management", The Canadian journal of hospital pharmacy, Vol. 68, No. 3, pp. 226-271. https://doi.org/10.4212/cjhp.v68i3.1456.

Velayutham, S. (2014) "Conventional" accounting vs "Islamic" accounting: the debate revisited", Journal of Islamic Accounting and Business Research, Vol. 5, No. 2, pp. 126-141, https://doi.org/10.1108/JIABR-05-2012-0026.

Zain, M. F. (2018) "Mining-trading cryptocurrency dalam hukum Islam" AlManahij: Journal Kajian Hukum Islam, Vol. 12, No. 1, pp. 119-132. https://doi. org/10.24090/mnh.v12i1.1303. 


\title{
Kvalitativni pristup procjeni pomirenja GOLDX-a i OneGrama u islamskim
} financijama

\author{
Marwan Mohamed ABDELDAYEM ${ }^{1}$, Saeed Hameed AL DULAIMI', \\ Fuaad Hameed AL DULAIMI
}

\begin{abstract}
Sažetak
Svrha ove studije je dvostruka. Prva svrha je ispitati percepciju islamskih stručnjaka za financije $i$ šerijatskih znanstvenika o islamskoj kriptovaluti ( $t$. GOLDX i OneGram). Pitanje je ima li ona ulogu u prihvaćanju kriptovaluta u islamskim financijama. Drugo je predstavljanje nove islamske kriptovalute koja će služiti tim bogatim islamskim populacijama. U radu se primjenjuje kvalitativni pristup istraživanja provodeći intervjue za istraživanje stavova islamskih znanstvenika o okviru nove islamske kriptovalute. Smatralo se potrebnim da znanstvenici posjeduju sveobuhvatno znanje i imaju veliko iskustvo u islamskom šerijatu i kriptovaluti. U skladu s tim, broj znanstvenika bio je ograničen i na kraju, samo je pet znanstvenika iz različitih islamskih zemalja ispunjavalo te posebne uvjete. Temeljito smo analizirali prikupljene podatke iz intervjua. Rezultati istraživanja ukazuju na činjenicu da u islamskom zakonu ne postoji model za utvrđivanje legitimnog $i$ nedozvoljenog korištenja $i$ razmjene konvencionalne kriptovalute (kao što je Bitcoin). Slijedom toga, uvođenje novih islamskih kriptovaluta je prihvaćanje kriptovaluta kao što su GOLDX i OneGram, koji mogu imati vitalnu ulogu u privlačenju više od 1,5 milijardi muslimana širom svijeta da uđu u svijet kriptovaluta.
\end{abstract}

Ključne riječi: kriptovaluta, GOLDX, OneGram, Fintech, islamske financije

JEL klasifikacija: G15, G32

1 Docent, Cairo University, Egypt and College of Administrative Sciences, Applied Science University (ASU), P.O Box 5055 Manama, Kraljevina Bahrein. Znanstveni interes: korporativne financije, financije ponašanja i primijenjena istraživanja, kriptovaluta,. Tel.:+973 35121048 , E-mail: Marwan.abdeldayem@asu.edu.bh.(Osoba za kontakt).

2 Docent, College of Administrative Sciences, Applied Science University (ASU), P.O Box 5055 Manama, Kraljevina Bahrain. Znanstveni interes: upravljanje ljudskim potencijalima $i$ upravljanje promjenama.Tel.:+973 39998703.E-mail: Saeed.aldulaimi@asu.edu.bh.

3 Docent, College of Administrative Sciences, Applied Science University (ASU), P.O Box Docent, Bait al-Mashura Financijske konzultacije, Zemlje zaljevske suradnje. Znanstveni interes: islamskefinancije.E-mail:f.dulaimi@b-mashura.com. 